\title{
The Analysis of the Compassion Levels of the Classroom Teachers in Terms of Different Variables
}

\author{
Murat Çalışoğlu \\ Correspondence: Murat Çalişoğlu, Ass.Prof.Dr., Basic Education Department, Ağrı İbrahim Çeçen university, Ağrı, \\ Turkey.
}

Received: April 2, 2018

doi:10.11114/jets.v6i7.3137
Accepted: May 7, $2018 \quad$ Online Published: June 8, 2018

URL: https://doi.org/10.11114/jets.v6i7.3137

\begin{abstract}
A teacher should be just and compassionate to be a good teacher. If there is weakness in these two, what a pity for those children who are trained by that teacher! Because one of the biggest diseases of this time is that mercilessness and unjustness are the raising trends. The purpose of this study is to analyze the mercy levels of the classroom teachers in terms of different variables. The study was conducted on 227 classroom teachers, 132 females and 95 males, working in Ağrı Province, Turkey in 2017.

In the study, the Compassion Scale (CS) developed by Pommier (2011) and adapted to Turkish by Seher Akdeniz and Mehmet Engin Deniz was applied to the teachers. A statistical program was used to analyze the data. Frequency distribution to determine demographic characteristics, $t$ test to analyze the relationship between compassion level and two independent variables, and ANOVA variant analysis to analyze the relationship between compassion level and variables more than two were used in the analyses of the data. The difference between the variables was interpreted on the basis of p0.05 significance level.
\end{abstract}

According to the findings, it was determined that there is a significant difference between the level of compassion of the teachers and the gender, the settlement they work in, and their term of office. It was determined that the mean scores of male teachers were higher than the female teachers in the dimensions of indifference, disconnection and intercourse in the sub-dimensions of compassion level, the mean scores of the teachers working in the village in the sub-dimension of being aware of the sharing is higher than the teachers working in the city, and the mean scores of the teachers with 6-10 years of period of office is higher than those with 16 years of period of office in the sub-dimension of being aware of the sharing and the mean scores of the teachers with 5 years and below of period of office is higher than those with 6-10 years of period of office in the sub-dimension of disengagement.

It can be recommended that increasing the compassion levels of the teachers in social and school life will have a positive effect on their relationships with students. It is also of higher importance to analyze other variables which are thought to positively affect compassion.

Keywords: compassion level, classroom teachers, primary school

\section{Introduction}

Compassion is the feeling of pity leading people to do good to others (Sami, 1986). According to Gilbert (2005), it is a behavioral process which involves compassionate activities including some kind of empathic cognitive process related to understanding the source of pain, the desire to reduce the suffering of others. Sprecher and Fehr (2005) defined it as compassionate, sensitive (compassionate) love. Sensitive love is described as a behavioral, cognitive, and emotional attitude to support other people in times of distress (Sprecher and Fehr, 2005).

The word of "merhamet" originating from the word "rahim" comes from the same root as the words of "rahman", "rahim", "rahmet" and "merhamet" (mercy, compassion" (Gök, 2015). Compassion, according to Aristoteles, is "the feeling of pain we feel when we see that a devastating or painful evil happens to someone who does not deserve it that it can happen to us or one of our friends and moreover it can happen sooner."

From the religious sources, the word compassion is defined with the concept of mercy which is expressed as the desire to deliver the good to the created ones (Cürcani, 1997). The concepts of compassion (merhamet) and mercy (rahmet) mean to feel sorry for someone, to protect, to forgive, to give one's daily bread and originate from the Arabic root 
"r-h-m." The word Rahim (merciful) originating from the root r-h-m is defined as being merciful (Karaman, 2006). This word is one of the names of Allah which is used the most in Kur-an (er-Rahim, i.e. the merciful) and means the forgiver, the merciful and the saver (Gündüz, 1998).

Compassion is the feeling that occurs in individuals that desiring the created to meet with the good and to be helped (Kandemir, 1993: 159-163). It is also explained as the feeling of pity, being sincere, trying not to break heart, being tolerant as a result of the fact that others do not have the opportunities that an individual has (Avc1, 2007). According to Hökelekli (2011: 13-17) and Kandemir (1993), compassion is broad and unbounded feeling. It takes its source from a divine and profound feeling.

Education can be defined as knowing the story of the universe, the earth, the system of living organisms and consciousness, and knowing the role of the human in this story. The preliminary purpose of education is to provide the individuals to fulfill their roles in this broad meaning (Langford, 1999). While mentioning changes and developments like a different world order, globalization, opening up to the world and reorganization, the individuals who are to be trained through education to keep up with all these changes are expected to have characteristics like researcher, questioning, problem solving, critical thinking, learning to learn, generating knowledge, creative, flexible, using technology, expressing his/her thoughts easily and clearly, and involving in team work (Şen, 2002).

The teachers who are accepted to have an important function in this development are expected to have some characteristics like understanding these changes and developments, interpreting, internalizing values and behaviors like effectiveness and quality, which is important in terms of providing quality for educational services. Effective teachers are the individuals who "are thinking, ask questions, criticize, are open to changes and innovations, constantly adopt themselves to what's new, like their profession" (Kavcar, 1999).

Today it is known that education is an important tool in the development of individuals and societies, and that countries economically prepare and spend the most money on it. It is only possible with effective communication of the teachers who have an important place in reaching the desired goals and objectives of the education with the students to transfer the desired knowledge and skills. It is known that empathy skills are important for teachers to communicate effectively and it is thought that the feeling of mercy can be effective in establishing good empathy.

\section{Material and Method}

The purpose of this study is to analyze the compassion levels of the teachers in terms of different variables. The study was conducted on the classroom teachers working in Ağrl Province, Turkey in 2017.

As a result of the literature review, few studies were found both in national and international indexes. In this term, it is though that this study will make an important contribution to the literature.

The study is a descriptive study which aims to determine the compassion levels of the teachers in terms of gender, age, marital status, family structure, whether having children, period of office, and the place they work in. The study is conducted in descriptive survey model among quantitative research methods. Descriptive survey model research aims to collect data to determine the specific characteristics of a group (Büyüköztürk,2015). In this type of research, questionnaire is filled, or individuals are interviewed to learn their attitudes, beliefs and thoughts. In descriptive survey model research, the researcher can generally make generalizations about the population by moving from the sample (Christensen, Johnson and Turner, 2014).

The independent variables used in the study were prepared by the researcher. This study was conducted on 227 classroom teachers, 132 females and 95 males, with an average age of 35 who work as a classroom teacher in Ağr Province, Turkey in 2017. In the study, the Compassion Scale (CS) developed by Pommier (2011) and adapted to Turkish by Seher Akdeniz and Mehmet Engin Deniz was used to determine the relationship between independent variables and compassion levels.

The Cronbach Alpha internal consistency reliability coefficient for all the scale was found to be .85 . When the internal consistency reliability coefficient for the sub-dimensions was calculated, it was calculated as .73 for humaneness $(6,8,16,24), .64$ for indifference $(2,12,14,18), .66$ for consciousness of sharing $(11,15,17,20), .67$ for disconnection $(3,5,10,22), .70$ for conscious awareness $(4,9,13,21)$ and .60 for disengagement $(1,7,19,23)$ (Akdeniz, and Deniz, 2016). In the analysis of the data, frequency distribution to determine the demographic characteristics, $t$ test to examine the relation between two independent variables, Anova analysis of variance test to analyze the relation between two or more variables were used in the study. The LSD test was used to determine the group from which the differences originated. All these tests were analyzed in the statistical program and the level of significance was taken as $p<0,05$. The Alpha value was found to be 0.711 in the analysis of reliability and validity. 


\section{Findings}

In this section, the frequency distributions of the demographic characteristics of the teachers participating in the research, the Independent-Samples $T$ test analysis results to determine the relationship between the two independent variables and the compassion subscales, and the One-Way Anova test analysis results to determine the relationship between the multiple variables and the compassion subscales are given.

Table 1: The Demographic Characteristics of the Teachers Participating in the Study

\begin{tabular}{|c|c|c|c|c|}
\hline \multicolumn{2}{|c|}{ Variables } & Number $(\mathbf{N})$ & Percentage (\%) & Total Percentage (\%) \\
\hline \multirow{3}{*}{ Gender } & Male & 95 & 41,9 & 41,9 \\
\hline & Female & 132 & 58,1 & 100,0 \\
\hline & Total & 227 & 100,0 & \\
\hline \multirow[b]{3}{*}{ Age } & 30-year-old and below & 132 & 58,1 & 58,1 \\
\hline & $31-40$ & 69 & 30,4 & 88,5 \\
\hline & 41-year-old and above & 26 & 11,5 & 100,0 \\
\hline \multirow[t]{2}{*}{ Marital Status } & Married & 78 & 34,4 & 34,4 \\
\hline & Single & 149 & 65,6 & 100,0 \\
\hline \multirow{3}{*}{ Family Structure } & Nuclear & 166 & 73,1 & 73,1 \\
\hline & Extended & 58 & 25,6 & 98,7 \\
\hline & Broken & 3 & 1,3 & 100,0 \\
\hline \multirow[t]{2}{*}{ Have children } & Yes & 73 & 32,2 & 32,2 \\
\hline & No & 154 & 67,8 & 100,0 \\
\hline \multirow{4}{*}{ The number of Children } & 1 child & 22 & 9,7 & 9,7 \\
\hline & 2 children & 34 & 15,0 & 24,7 \\
\hline & 3 children and above & 17 & 7,5 & 32,2 \\
\hline & No children & 154 & 67,8 & 100,0 \\
\hline \multirow[t]{2}{*}{ The Gender of the Children } & Female & 48 & 21,1 & 65,8 \\
\hline & Male & 25 & 11,0 & 100,0 \\
\hline \multirow{4}{*}{ Period of Office } & 5 years and below & 109 & 48,0 & 48,0 \\
\hline & $6-10$ & 55 & 24,2 & 72,2 \\
\hline & $11-15$ & 30 & 13,2 & 85,5 \\
\hline & 16 years and above & 33 & 14,5 & 100,0 \\
\hline \multirow[t]{2}{*}{ The Place you work in } & City & 204 & 89,9 & 89,9 \\
\hline & Village & 23 & 10,1 & 100,0 \\
\hline
\end{tabular}

Table 2. T Values of the Scores of Female and Male Teachers from Compassion Subscales

\begin{tabular}{|c|c|c|c|c|c|c|c|}
\hline Sub-scales & Gender & $\mathbf{N}$ & $\mathbf{X}$ & Ss & $\mathbf{t}$ & $\begin{array}{c}\text { Mean } \\
\text { Difference }\end{array}$ & $\begin{array}{c}\text { Sig. } \\
\text { (2-tailed) }\end{array}$ \\
\hline \multirow[b]{2}{*}{ Humaneness } & Male & 95 & 17,3263 & 2,36752 & $-1,760$ & \multirow[b]{2}{*}{,- 52217} & \multirow[b]{2}{*}{, 080} \\
\hline & Female & 132 & 17,8485 & 2,08039 & $-1,724$ & & \\
\hline \multirow[b]{2}{*}{ Indifference } & Male & 95 & 7,7053 & 2,99245 & 4,257 & \multirow[b]{2}{*}{1,50829} & \multirow[b]{2}{*}{, $000 *$} \\
\hline & Female & 132 & 6,1970 & 2,34257 & 4,092 & & \\
\hline \multirow{2}{*}{$\begin{array}{l}\text { Being aware of the } \\
\text { sharing }\end{array}$} & Male & 95 & 17,3053 & 2,15403 &,- 634 & \multirow[b]{2}{*}{,- 17959} & \multirow[b]{2}{*}{, 527} \\
\hline & Female & 132 & 17,4848 & 2,06935 &,- 630 & & \\
\hline \multirow[b]{2}{*}{ Disconnection } & Male & 95 & 7,6737 & 2,45141 & 3,053 & \multirow[b]{2}{*}{,96914 } & \multirow[b]{2}{*}{, $003 *$} \\
\hline & Female & 132 & 6,7045 & 2,29083 & 3,020 & & \\
\hline \multirow{2}{*}{$\begin{array}{c}\text { Conscious } \\
\text { Awareness }\end{array}$} & Male & 95 & 17,0632 & 1,99366 &,- 788 & \multirow[b]{2}{*}{,- 21715} & \multirow[b]{2}{*}{,432 } \\
\hline & Female & 132 & 17,2803 & 2,08709 &,- 794 & & \\
\hline \multirow[b]{2}{*}{ Disengagement } & Male & 95 & 6,7579 & 2,89429 & 2,158 & \multirow[b]{2}{*}{,72002 } & \multirow[b]{2}{*}{, $032 *$} \\
\hline & Female & 132 & 6,0379 & 2,13443 & 2,056 & & \\
\hline
\end{tabular}

It was determined that there is a significant difference at P:0,05 significance level between the average of points of the male and female teachers from the compassion sub-dimensions in terms of indifference ${ }_{(\mathbf{p} ;, 000)}$, disconnection ${ }_{(\mathbf{p}: 003)}$ and

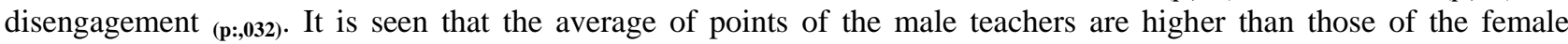
teachers in terms of indifference, disconnection and disengagement sub-dimensions.

It was determined that there is no significant difference at $\mathrm{P} ; 0,05$ significance level between the average of points in terms of humaneness, being aware of the sharing and conscious awareness sub-dimensions. 
Table 3. The Marital Status of the Teachers and t Values of the Scores of Teachers from Compassion Subscales

\begin{tabular}{|c|c|c|c|c|c|c|c|}
\hline Subscales & Marital Status & $\mathbf{N}$ & $\mathbf{X}$ & Ss & $\mathbf{t}$ & Mean Difference & Sig. (2-tailed) \\
\hline \multirow[b]{2}{*}{ Humaneness } & Married & 78 & 17,5769 & 2,51499 &,- 260 & \multirow[t]{2}{*}{,- 08080} & \multirow[t]{2}{*}{,795 } \\
\hline & Single & 149 & 17,6577 & 2,04930 &,- 244 & & \\
\hline \multirow[b]{2}{*}{ Indifference } & Married & 78 & 6,7821 & 2,93942 &,- 184 & \multirow[t]{2}{*}{,- 07030} & \multirow[t]{2}{*}{,854 } \\
\hline & Single & 149 & 6,8523 & 2,62621 &,- 177 & & \\
\hline \multirow[t]{2}{*}{ Being aware of the sharing } & Married & 78 & 17,1282 & 2,34858 & $-1,463$ & \multirow[t]{2}{*}{,- 42884} & \multirow[t]{2}{*}{, 145} \\
\hline & Single & 149 & 17,5570 & 1,95345 & $-1,382$ & & \\
\hline \multirow[b]{2}{*}{ Disconnection } & Married & 78 & 7,0641 & 2,33182 &,- 208 & \multirow[t]{2}{*}{,- 07013} & \multirow[t]{2}{*}{835} \\
\hline & Single & 149 & 7,1342 & 2,44578 &,- 212 & & \\
\hline \multirow[t]{2}{*}{ Conscious Awareness } & Married & 78 & 17,2564 & 1,96354 & ,356 & \multirow[t]{2}{*}{, 10205 } & \multirow[t]{2}{*}{,722 } \\
\hline & Single & 149 & 17,1544 & 2,09480 & ,363 & & \\
\hline \multirow[b]{2}{*}{ Disengagement } & Married & 78 & 6,3974 & 2,73192 & ,253 & \multirow[t]{2}{*}{,08871 } & \multirow[t]{2}{*}{800} \\
\hline & Single & 149 & 6,3087 & 2,37924 & ,243 & & \\
\hline
\end{tabular}

It was determined that there is no significant difference at P;0,05 significance level between the average of points of the single and married teachers from the compassion subscales. Although there is no significance difference, it is seen that the scores of the single teachers in humaneness, indifference, being aware of sharing and disconnection sub-dimensions are higher than those of the married teachers in conscious awareness and disengagement sub-dimensions.

Table 4. Having Children Status and t Values of the Scores of the Teachers from Compassion Subscales

\begin{tabular}{|c|c|c|c|c|c|c|c|}
\hline Subscales & Have Children & $\mathbf{N}$ & $\mathbf{X}$ & Ss & $\mathbf{t}$ & $\begin{array}{c}\text { Mean } \\
\text { Difference }\end{array}$ & $\begin{array}{c}\text { Sig. } \\
\text { (2-tailed) }\end{array}$ \\
\hline \multirow[t]{2}{*}{ Humaneness } & Yes & 73 & 17,6438 & 2,37095 & ,065 & \multirow[t]{2}{*}{,02046 } & \multirow[t]{2}{*}{,948 } \\
\hline & No & 154 & 17,6234 & 2,14530 & ,063 & & \\
\hline \multirow[t]{2}{*}{ Indifference } & Yes & 73 & 6,6575 & 2,70914 &,- 647 & \multirow[t]{2}{*}{,- 25156} & \multirow[t]{2}{*}{,518 } \\
\hline & No & 154 & 6,9091 & 2,74722 &,- 650 & & \\
\hline \multirow{2}{*}{$\begin{array}{l}\text { Being aware of } \\
\text { the sharing }\end{array}$} & Yes & 73 & 17,1644 & 2,30346 & $-1,212$ & \multirow[t]{2}{*}{,- 36159} & \multirow[t]{2}{*}{,227 } \\
\hline & No & 154 & 17,5260 & 1,99738 & $-1,152$ & & \\
\hline \multirow[t]{2}{*}{ Indifference } & Yes & 73 & 6,9589 & 2,14371 &,- 652 & \multirow[t]{2}{*}{,- 22291} & \multirow[t]{2}{*}{, 515} \\
\hline & No & 154 & 7,1818 & 2,51909 &,- 691 & & \\
\hline \multirow{2}{*}{$\begin{array}{l}\text { Conscious } \\
\text { awareness }\end{array}$} & Yes & 73 & 17,3699 & 1,88198 & ,914 & \multirow[t]{2}{*}{,26597 } & \multirow[t]{2}{*}{,362 } \\
\hline & No & 154 & 17,1039 & 2,12107 & ,954 & & \\
\hline \multirow[b]{2}{*}{ Disengagement } & Yes & 73 & 6,2603 & 2,66681 &,- 327 & \multirow[t]{2}{*}{,- 11635} & \multirow[t]{2}{*}{,744 } \\
\hline & No & 154 & 6,3766 & 2,42557 &,- 316 & & \\
\hline
\end{tabular}

It was determined that there is no significant difference at P;0,05 significance level between the average of points of teachers and their status of having children or not. Even though there is no significant difference, the teachers who have children have higher scores in humaneness and conscious awareness sub-dimensions, and the teachers who don't have any children have higher scores in indifference, being aware of the sharing, disconnection and disengagement sub-dimensions. 
Table 4. Gender of the Teachers' Children and t Values of the Scores from Compassion Subscales

\begin{tabular}{|c|c|c|c|c|c|c|c|}
\hline Subscales & $\begin{array}{l}\text { Gender of the } \\
\text { Children }\end{array}$ & $\mathbf{N}$ & $\mathbf{X}$ & Ss & $\mathbf{t}$ & $\begin{array}{c}\text { Mean } \\
\text { Difference }\end{array}$ & $\begin{array}{c}\text { Sig. } \\
\text { (2-tailed) }\end{array}$ \\
\hline \multirow[t]{2}{*}{ Humaneness } & Female & 48 & 17,6042 & 2,07046 &,- 197 & \multirow[t]{2}{*}{,- 11583} & \multirow[t]{2}{*}{845} \\
\hline & Male & 25 & 17,7200 & 2,90861 &,- 177 & & \\
\hline \multirow[t]{2}{*}{ Indifference } & Female & 48 & 7,0417 & 2,61711 & 1,701 & \multirow[t]{2}{*}{1,12167} & \multirow[t]{2}{*}{,093 } \\
\hline & Male & 25 & 5,9200 & 2,78268 & 1,668 & & \\
\hline \multirow{2}{*}{$\begin{array}{l}\text { Being aware of } \\
\text { the sharing }\end{array}$} & Female & 48 & 17,2708 & 2,33146 & ,544 & \multirow[t]{2}{*}{,31083 } & \multirow[t]{2}{*}{,588 } \\
\hline & Male & 25 & 16,9600 & 2,28181 & ,548 & & \\
\hline \multirow[t]{2}{*}{ Disconnection } & Female & 48 & 7,0000 & 2,19283 & ,225 & \multirow[t]{2}{*}{,12000 } & \multirow[t]{2}{*}{822} \\
\hline & Male & 25 & 6,8800 & 2,08806 & ,229 & & \\
\hline \multirow{2}{*}{$\begin{array}{l}\text { Conscious } \\
\text { awareness }\end{array}$} & Female & 48 & 17,4167 & 1,77252 & ,293 & \multirow[t]{2}{*}{,13667 } & \multirow[t]{2}{*}{,771 } \\
\hline & Male & 25 & 17,2800 & 2,11187 & ,277 & & \\
\hline \multirow[b]{2}{*}{ Disengagement } & Female & 48 & 6,3958 & 2,84148 & ,599 & \multirow[t]{2}{*}{,39583 } & \multirow[t]{2}{*}{,551 } \\
\hline & Male & 25 & 6,0000 & 2,32737 & ,638 & & \\
\hline
\end{tabular}

It was determined that there is no significant difference at P;0,05 significance level between the average of points of teachers and the gender of their children. Despite the non-significant difference, the teachers who have daughters have higher scores in indifference, being aware of sharing, disconnection, conscious awareness and disengagement sub-dimensions, and the teachers who have sons have higher scores in humaneness sub-dimension.

Table 5. The Place the Teachers Work in and the t Values of the Scores from the Compassion Sub-dimensions

\begin{tabular}{|c|c|c|c|c|c|c|c|}
\hline Subscales & Place of Duty & $\mathbf{N}$ & $\mathbf{X}$ & Ss & $\mathbf{t}$ & $\begin{array}{c}\text { Mean } \\
\text { Difference }\end{array}$ & $\begin{array}{c}\text { Sig. } \\
\text { (2-tailed) }\end{array}$ \\
\hline \multirow[t]{2}{*}{ Humaneness } & City & 204 & 17,6029 & 2,26652 &,- 546 & \multirow[t]{2}{*}{,- 26662} & \multirow[t]{2}{*}{,585 } \\
\hline & Village & 23 & 17,8696 & 1,71370 &,- 682 & & \\
\hline \multirow[t]{2}{*}{ Indifference } & City & 204 & 6,9069 & 2,77145 & 1,294 & \multirow[t]{2}{*}{,77643 } & \multirow[t]{2}{*}{,197 } \\
\hline & Village & 23 & 6,1304 & 2,28243 & 1,511 & & \\
\hline \multirow{2}{*}{$\begin{array}{l}\text { Being aware of the } \\
\text { sharing }\end{array}$} & City & 204 & 17,2892 & 2,09378 & $-2,604$ & \multirow[t]{2}{*}{$-1,18905$} & \multirow[t]{2}{*}{, $010 *$} \\
\hline & Village & 23 & 18,4783 & 1,90381 & $-2,810$ & & \\
\hline \multirow[t]{2}{*}{ Disconnection } & City & 204 & 7,0098 & 2,39044 & $-1,885$ & \multirow[t]{2}{*}{,- 99020} & \multirow[t]{2}{*}{,061 } \\
\hline & Village & 23 & 8,0000 & 2,37410 & $-1,895$ & & \\
\hline \multirow{2}{*}{$\begin{array}{l}\text { Conscious } \\
\text { awareness }\end{array}$} & City & 204 & 17,1814 & 2,02726 &,- 176 & \multirow[t]{2}{*}{,- 07950} & \multirow[t]{2}{*}{860} \\
\hline & Village & 23 & 17,2609 & 2,26068 &,- 161 & & \\
\hline \multirow[t]{2}{*}{ Disengagement } & City & 204 & 6,3431 & 2,53058 & ,070 & \multirow[t]{2}{*}{03879} & \multirow[t]{2}{*}{,944 } \\
\hline & Village & 23 & 6,3043 & 2,26505 & ,077 & & \\
\hline
\end{tabular}

It was determined that there is significant difference at $\mathrm{P} ; 0,05$ significance level between the scores of the teachers from the compassion subscales and the place they work in in terms of being aware of sharing $(\mathbf{p} ; \mathbf{0 1 0 )}$. It can be seen that the scores of the teachers working in the village are higher than those of the teachers working in the city. It was determined that there is no significant difference at $\mathrm{P} ; 0,05$ significance level in terms of humaneness, indifference, disconnection, conscious awareness and disengagement. 
Table 6. Family Structure of the Teachers and t Values of their Scores from Compassion Subscales

\begin{tabular}{|c|c|c|c|c|c|c|c|}
\hline Subscales & Family Structure & $\mathbf{N}$ & $\mathbf{X}$ & Ss & $\mathbf{t}$ & Mean Difference & Sig. (2-tailed) \\
\hline \multirow[t]{2}{*}{ Humaneness } & Nuclear & 166 & 17,7771 & 1,98594 & 1,373 & \multirow[t]{2}{*}{,44952 } & \multirow[t]{2}{*}{, 171} \\
\hline & Extended & 58 & 17,3276 & 2,55733 & 1,217 & & \\
\hline \multirow[t]{2}{*}{ Indifference } & Nuclear & 166 & 6,6446 & 2,46924 & $-1,521$ & \multirow[t]{2}{*}{,- 61404} & \multirow[t]{2}{*}{, 130 } \\
\hline & Extended & 58 & 7,2586 & 3,10382 & $-1,363$ & & \\
\hline \multirow[t]{2}{*}{ Being aware of sharing } & Nuclear & 166 & 17,4639 & 2,00799 & 649 & \multirow[t]{2}{*}{,20523 } & \multirow[t]{2}{*}{,517 } \\
\hline & Extended & 58 & 17,2586 & 2,25218 & ,614 & & \\
\hline \multirow[t]{2}{*}{ Disconnection } & Nuclear & 166 & 7,0422 & 2,28129 &,- 462 & \multirow[t]{2}{*}{,- 16473} & \multirow[t]{2}{*}{,645 } \\
\hline & Extended & 58 & 7,2069 & 2,49743 &,- 442 & & \\
\hline \multirow[t]{2}{*}{ Conscious awareness } & Nuclear & 166 & 17,2711 & 1,99818 & ,768 & \multirow[t]{2}{*}{,23660 } & \multirow[t]{2}{*}{,443 } \\
\hline & Extended & 58 & 17,0345 & 2,07716 &, 754 & & \\
\hline \multirow[b]{2}{*}{ Disengagement } & Nuclear & 166 & 6,1988 & 2,18041 & $-1,257$ & \multirow[t]{2}{*}{,- 47362} & \multirow[t]{2}{*}{,210 } \\
\hline & Extended & 58 & 6,6724 & 3,16443 & $-1,056$ & & \\
\hline
\end{tabular}

It was determined that there is no significant difference at P;0,05 significance level between the average of points of teachers with nuclear or extended family. Although there is no significant difference, it can be seen that the scores of the teachers with nuclear family are higher in humaneness, being aware of sharing and conscious awareness sub-dimensions, and the score of the teachers with extended family are higher in indifference, disconnection and disengagement sub-dimensions.

Table 7. Average Scores and the Values of Standard Deviation and Differences between the Averages of the Teachers within Different Age Groups from the Compassion Subscales

\begin{tabular}{|c|c|c|c|c|c|c|c|}
\hline Subscales & Age & $\mathbf{N}$ & $\mathbf{X}$ & Ss & $\mathbf{f}$ & $\mathbf{P}$ & Difference \\
\hline \multirow{4}{*}{ Humaneness } & 30-year-old and below (1) & 132 & 17,5076 & 2,14546 & \multirow{4}{*}{,447 } & \multirow{4}{*}{, 335} & \\
\hline & $31-40(2)$ & 69 & 17,8261 & 2,33236 & & & \\
\hline & 41-year-old and above (3) & 26 & 17,7308 & 2,29011 & & & \\
\hline & Total & 227 & 17,6300 & 2,21511 & & & \\
\hline \multirow{4}{*}{ Indifference } & 30-year-old and below (1) & 132 & 6,8409 & 2,74023 & \multirow{4}{*}{,284 } & \multirow{4}{*}{, 454} & \\
\hline & $31-40(2)$ & 69 & 6,6812 & 2,47037 & & & \\
\hline & 41-year-old and above (3) & 26 & 7,1538 & 3,36681 & & & \\
\hline & Total & 227 & 6,8282 & 2,73158 & & & \\
\hline \multirow{4}{*}{ Being aware of sharing } & 30-year-old and below (1) & 132 & 17,3712 & 2,06536 & \multirow{4}{*}{, 059} & \multirow{4}{*}{,733 } & \multirow{4}{*}{---} \\
\hline & $31-40(2)$ & 69 & 17,4783 & 2,25316 & & & \\
\hline & 41-year-old and above (3) & 26 & 17,4231 & 1,94264 & & & \\
\hline & Total & 227 & 17,4097 & 2,10236 & & & \\
\hline \multirow{4}{*}{ Disconnection } & 30-year-old and below (1) & 132 & 7,2348 & 2,64390 & \multirow{4}{*}{, 522} & \multirow{4}{*}{,308 } & \multirow{4}{*}{----- } \\
\hline & $31-40(2)$ & 69 & 6,8696 & 2,09280 & & & \\
\hline & 41-year-old and above (3) & 26 & 7,1154 & 1,84015 & & & \\
\hline & Total & 227 & 7,1101 & 2,40229 & & & \\
\hline \multirow[t]{4}{*}{ Conscious awareness } & 30-year-old and below (1) & 132 & 17,0076 & 2,08410 & \multirow{4}{*}{1,326} & \multirow{4}{*}{, 196} & \multirow{4}{*}{---- } \\
\hline & $31-40(2)$ & 69 & 17,3913 & 2,08790 & & & \\
\hline & 41-year-old and above (3) & 26 & 17,5769 & 1,67745 & & & \\
\hline & Total & 227 & 17,1894 & 2,04686 & & & \\
\hline \multirow{4}{*}{ Disengagement } & 30-year-old and below (1) & 132 & 6,3939 & 2,48279 & \multirow{4}{*}{, 117} & \multirow{4}{*}{,636 } & \multirow{4}{*}{---- } \\
\hline & $31-40(2)$ & 69 & 6,2174 & 2,41240 & & & \\
\hline & 41-year-old and above (3) & 26 & 6,3846 & 2,88551 & & & \\
\hline & Total & 227 & 6,3392 & 2,50034 & & & \\
\hline
\end{tabular}

It was determined that there is no significant difference at P;0,05 significance level between the average of points of teachers and their age groups. 
Table 8. The Number of the Children the Teachers have and Their Scores and the Values of Standard Deviation and Differences between the Averages from the Compassion Subscales

\begin{tabular}{|c|c|c|c|c|c|c|c|}
\hline Subscales & The Number of the Children & $\mathbf{N}$ & $\mathbf{X}$ & Ss & $\mathbf{f}$ & $\mathbf{P}$ & Difference \\
\hline \multirow{4}{*}{ Humaneness } & 1 child (1) & 22 & 18,0455 & 2,01133 & \multirow{4}{*}{1,819} & \multirow{4}{*}{, 081} & \multirow{4}{*}{----- } \\
\hline & 2 children $(2)$ & 34 & 17,8529 & 1,95607 & & & \\
\hline & 3 children and above (3) & 17 & 16,7059 & 3,29326 & & & \\
\hline & Total & 73 & 17,6438 & 2,37095 & & & \\
\hline \multirow{4}{*}{ Indifference } & 1 child $(1)$ & 22 & 6,4545 & 2,80692 & \multirow{4}{*}{1,336} & \multirow{4}{*}{, 197 } & \multirow{4}{*}{-----} \\
\hline & 2 children $(2)$ & 34 & 6,3235 & 2,19808 & & & \\
\hline & 3 children and above $(3)$ & 17 & 7,5882 & 3,39225 & & & \\
\hline & Total & 73 & 6,6575 & 2,70914 & & & \\
\hline \multirow[t]{4}{*}{ Being aware of sharing } & 1 child $(1)$ & 22 & 16,9545 & 2,51618 & \multirow{4}{*}{, 128} & \multirow{4}{*}{,628 } & \multirow{4}{*}{--- } \\
\hline & 2 children (2) & 34 & 17,2647 & 2,10783 & & & \\
\hline & 3 children and above (3) & 17 & 17,2353 & 2,51320 & & & \\
\hline & Total & 73 & 17,1644 & 2,30346 & & & \\
\hline \multirow{4}{*}{ Disconnection } & 1 child (1) & 22 & 7,3636 & 2,08271 & \multirow{4}{*}{2,170} & \multirow{4}{*}{,079 } & \multirow{4}{*}{----- } \\
\hline & 2 children (2) & 34 & 6,4118 & 2,18975 & & & \\
\hline & 3 children and above (3) & 17 & 7,5294 & 1,97223 & & & \\
\hline & Total & 73 & 6,9589 & 2,14371 & & & \\
\hline \multirow[t]{4}{*}{ Conscious awareness } & 1 child (1) & 22 & 17,0455 & 1,91429 & \multirow{4}{*}{,495 } & \multirow{4}{*}{,326 } & \multirow{4}{*}{--- } \\
\hline & 2 children $(2)$ & 34 & 17,5588 & 1,65495 & & & \\
\hline & 3 children and above ( 3 ) & 17 & 17,4118 & 2,29289 & & & \\
\hline & Total & 73 & 17,3699 & 1,88198 & & & \\
\hline \multirow{4}{*}{ Disengagement } & 1 child $(1)$ & 22 & 6,1364 & 2,81654 & \multirow{4}{*}{1,582} & \multirow{4}{*}{,083 } & \multirow{4}{*}{----} \\
\hline & 2 children $(2)$ & 34 & 5,8529 & 2,17607 & & & \\
\hline & 3 children and above ( 3 ) & 17 & 7,2353 & 3,23128 & & & \\
\hline & Total & 73 & 6,2603 & 2,66681 & & & \\
\hline
\end{tabular}

It was determined that there is no significant difference at $\mathrm{P} ; 0,05$ significance level between the average of points of teachers and the number of the children they have. 
Table 9. Period of Office of the Teachers and Their Scores and the Values of Standard Deviation and Differences between the Averages from the Compassion Subscales

\begin{tabular}{|c|c|c|c|c|c|c|c|}
\hline Subscales & Period of Office & $\mathbf{N}$ & $\mathbf{X}$ & Ss & $\mathbf{f}$ & $\mathbf{P}$ & Difference \\
\hline \multirow[t]{5}{*}{ Humaneness } & $\begin{array}{l}5 \text { years and } \\
\text { below (1) }\end{array}$ & 109 & 17,4128 & 2,25754 & \multirow{5}{*}{, 965} & \multirow{5}{*}{, 134} & \multirow{5}{*}{------ } \\
\hline & 6-10 (2) & 55 & 17,8364 & 2,02543 & & & \\
\hline & $11-15(3)$ & 30 & 18,1000 & 2,35401 & & & \\
\hline & $\begin{array}{c}16 \text { years and } \\
\text { above }(4)\end{array}$ & 33 & 17,5758 & 2,25042 & & & \\
\hline & Total & 227 & 17,6300 & 2,21511 & & & \\
\hline \multirow[t]{5}{*}{ Indifference } & $\begin{array}{c}5 \text { years and } \\
\text { below (1) }\end{array}$ & 109 & 7,0183 & 2,88348 & \multirow{5}{*}{,465 } & \multirow{5}{*}{,246 } & \multirow{5}{*}{----- } \\
\hline & 6-10 (2) & 55 & 6,4909 & 2,56669 & & & \\
\hline & 11-15 (3) & 30 & 6,7333 & 2,36254 & & & \\
\hline & $\begin{array}{l}16 \text { years and } \\
\text { above (4) }\end{array}$ & 33 & 6,8485 & 2,85177 & & & \\
\hline & Total & 227 & 6,8282 & 2,73158 & & & \\
\hline \multirow[t]{5}{*}{$\begin{array}{l}\text { Being aware of } \\
\text { sharing }\end{array}$} & $\begin{array}{l}5 \text { years and } \\
\text { below (1) }\end{array}$ & 109 & 17,2661 & 2,07115 & \multirow{5}{*}{1,721} & \multirow{5}{*}{, $043 *$} & \multirow{5}{*}{$2>4$} \\
\hline & 6-10 (2) & 55 & 17,9091 & 1,85864 & & & \\
\hline & 11-15(3) & 30 & 17,5000 & 2,37443 & & & \\
\hline & $\begin{array}{l}16 \text { years and } \\
\text { above (4) }\end{array}$ & 33 & 16,9697 & 2,25672 & & & \\
\hline & Total & 227 & 17,4097 & 2,10236 & & & \\
\hline \multirow[t]{5}{*}{ Disconnection } & $\begin{array}{l}5 \text { years and } \\
\text { below (1) }\end{array}$ & 109 & 7,3853 & 2,79188 & \multirow{5}{*}{1,208} & \multirow{5}{*}{, 060} & \multirow{5}{*}{----- } \\
\hline & 6-10 (2) & 55 & 6,6364 & 1,78848 & & & \\
\hline & 11-15 (3) & 30 & 7,0333 & 2,09241 & & & \\
\hline & $\begin{array}{l}16 \text { years and } \\
\text { above (4) }\end{array}$ & 33 & 7,0606 & 2,10564 & & & \\
\hline & Total & 227 & 7,1101 & 2,40229 & & & \\
\hline \multirow[t]{5}{*}{$\begin{array}{l}\text { Conscious } \\
\text { awareness }\end{array}$} & $\begin{array}{l}5 \text { years and } \\
\text { below (1) }\end{array}$ & 109 & 17,0275 & 2,21300 & \multirow{5}{*}{,566 } & \multirow{5}{*}{, 233} & \multirow{5}{*}{---} \\
\hline & 6-10 (2) & 55 & 17,3091 & 1,56196 & & & \\
\hline & 11-15 (3) & 30 & 17,2000 & 2,49689 & & & \\
\hline & $\begin{array}{l}16 \text { years and } \\
\text { above (4) }\end{array}$ & 33 & 17,5152 & 1,75216 & & & \\
\hline & Total & 227 & 17,1894 & 2,04686 & & & \\
\hline \multirow[t]{5}{*}{ Disengagement } & $\begin{array}{c}5 \text { years and } \\
\text { below (1) }\end{array}$ & 109 & 6,5780 & 2,61864 & \multirow{5}{*}{1,810} & \multirow{5}{*}{,029* } & \multirow{5}{*}{$1>2$} \\
\hline & 6-10 (2) & 55 & 5,6727 & 1,87631 & & & \\
\hline & $11-15(3)$ & 30 & 6,3667 & 2,61934 & & & \\
\hline & $\begin{array}{l}16 \text { years and } \\
\text { above (4) }\end{array}$ & 33 & 6,6364 & 2,79305 & & & \\
\hline & Total & 227 & 6,3392 & 2,50034 & & & \\
\hline
\end{tabular}

It was determined that there is significant difference at $\mathrm{P} ; 0,05$ significance level between period of office of the teachers and their average scores in being aware of sharing ${ }_{(\mathbf{p} ; \mathbf{0 4 3})}$ disengagement $_{(\mathbf{p} ; \mathbf{0 2 9})}$ sub-dimensions. The average scores of the teachers with 6-10 years of period of office than those of the teachers with 16 years and above period of office in being aware of sharing sub-dimension. The average scores of the teachers with 5 years and below period of office are higher than those of 6-10 years of period of office in disengagement sub-dimension.

It was determined that there is no significant difference at P;0,05 significance level in humaneness, indifference, disconnection and conscious awareness sub-dimensions.

\section{Results and Discussion}

This study which was carried out to analyze the compassion levels of the classroom teachers in terms of different variables was conducted on 227 teachers, 132 females and 95 males, working in secondary schools in Ağr Province in 2017-2018 academic years.

It was determined that there is significant difference between gender and the scores of the teachers from the compassion subscales in terms of indifference, disconnection and disengagement sub-dimensions. It was concluded that the compassion attitude levels of the male teachers are higher than those of the female teachers in terms of indifference, disconnection and disengagement sub-dimensions. It was determined that there is no significant difference in 
humaneness, being aware of sharing and conscious awareness sub-dimensions. In the study conducted by Çingöl et al. on the students of health school, it was found that there is significant difference between the compassion levels on behalf of females in terms of gender (Çingöl, 2016). In the study conducted with university students by Tatum, it was determined that there is significant difference between the genders.

It was found that there is no significant difference between the marital status and the average scores of the teachers from the compassion subscales. Though there is no significant difference, the compassion levels of the single teachers are higher in humaneness, indifference, being aware of sharing and disconnection sub-dimensions, and the compassion levels of the married teachers are higher in conscious awareness and disengagement sub-dimensions.

It was determined that there is no significant difference between the having children status and the average scores of the teachers from the compassion subscales. Despite the non-significant difference, the compassion levels of the teachers who have children are higher in humaneness and conscious awareness sub-dimensions, and the compassion levels of the teachers who don't have children are higher in indifference, being aware of sharing, disconnection and disengagement sub-dimensions.

It was found out that there is no significant difference between the gender of the children of the teachers and the average scores of the teachers from the compassion subscales. Although there is no significant difference, the compassion levels of the teachers who have daughters are higher in indifference, being aware of sharing, disconnection, conscious awareness and disengagement sub-dimensions, and the compassion levels of the teachers who have sons are higher in humaneness sub-dimension.

It was determined that there is significant difference between the place the teachers work in and the average scores from the compassion subscales in terms of being aware of sharing sub-dimension. It was found out that the compassion levels of the teachers working in the village are higher than those of the teachers working in the city in terms of being aware of sharing sub-dimensions. It was determined that there is no significant difference between the average scores in terms of humaneness, indifference, disconnection, conscious awareness and disengagement sub-dimensions.

It was determined that there is no significant difference between the age level, family structure and the number of the children the teachers have and the average scores of the teachers from the compassion subscales at $\mathrm{P} ; 0,05$ significance level. It was found that the compassion levels of the teachers who have nuclear family are higher in humaneness, being aware of sharing and conscious awareness sub-dimensions, and the compassion levels of the teachers who have extended family are higher in indifference, disconnection and disengagement sub-dimensions.

It was determined that there is significant difference between the period of office and the average scores of the teachers from the compassion sub-scales in terms of being aware of sharing and disengagement sub-dimensions. It was seen that the compassion levels of the teachers with 6-10 years of period of office are higher than those of the teachers with 16 years and above period of office in terms of being aware of sharing sub-dimension, and the compassion levels of the teachers with 5 years and below period of office are higher than those of the teachers with 6-10 years of period of office in terms of disengagement sub-dimension. It was determined that there is no significant difference in humaneness, indifference, disconnection and conscious awareness sub-dimensions.

It can be recommended that increasing the compassion levels of the teachers in social and school life will have a positive effect on their relationships with the students. Seminars, conference and various in-service trainings can be organized, which is thought to have a positive effect on the compassion levels of the teachers. Both the Ministry of National Education and school administration can provide self-help books for the teachers that can contribute to the compassion levels of the teachers. Moreover, it is of higher importance that other factors that are thought to have positive effects on compassion should be investigated.

\section{References}

Akdeniz, S., \& Deniz, M. E. (2016). Merhamet Olcegi'nin Turkceye Uyarlanmasi: Gecerlik ve Guvenirlik Calismasi. The Journal of Happiness \& Well-Being, 4(1), 50-61.

Avci, S. (2007). Yaratilana Sefkat ve Merhamet, Istanbul: Erkam Yayinlari.

Buyukozturk, S. (2015). Bilimsel arastirma yontemleri. Ankara: Pegem Akademi.

Christensen, L. B., Johnson, B., \& Turner, L. A. (2015). Arastirma yontemleri: Desen ve analiz. Ankara: Ani Yay.

Cingol, N., Celebi, E., Zengin, S., \& Karakas, M. Bir Saglik Yuksekokulu Hemsirelik Bolumu Ogrencilerinin Merhamet Duzeylerinin Incelenmesi.

Curcani, S. S. (1997). Arapca- Turkce Terimler Sozlugu, (Cev. A. Erkan), 1. Baski, Istanbul: Bahar Yayinlari.

Gilbert, P. (Ed.). (2005). Compassion: Conceptualisations, research and use in psychotherapy. Routledge. 
Gok, G. A. (2015). Merhamet etmenin dayanilmaz agirligi: hemsirelerde merhamet yorgunlugu. Suleyman Demirel Universitesi Iktisadi ve Idari Bilimler Fakultesi Dergisi, 20(2).

Gunduz, S. (1998). Din ve Inanc Sozlugu, 1. Baski, Ankara: Vadi Yayinlari.

Hokelekli, H. (2011). Gokyuzunden Yeryuzune Yayilan Bir Deger: Merhamet Egitimi, Diyanet Dergisi, 244, 13-17.

Kandemir, M. Y. (1993). Orneklerle Islam Ahlâki, 6. Baski, Istanbul: Nesil Yayinlari.

Karaman, F. (2006). Dini Kavramlar Sozlugu, Ankara: Diyanet Isleri Baskanligi Yayinlari.

Kavcar, C. (1999). "Nitelikli Ogretmen Sorunu", Egitimde Yansimalar: V. 21. Yuzyilin Esiginde Egitim Sistemi Ulusal Sempozyumu. Ankara.

Langford, D. P. (1999). Egitimde Kalite Yonetimi, KalDer Yayinlari (Cev:Meltem Sungur), No:20. Istanbul.

Pommier (2011). tarafindan gelistirilen Merhamet Olcegi'ni (MO) (Pommier, E. A. (2011). The compassion scale. Dissertation Abstracts International Section A: Humanities and Social Sciences, 72, 1174.)

Sen, H. S., \& Erisen, Y. (2002). Ogretmen Yetistiren Kurumlarda Ogretim Elemanlarinin Etkili Ogretmenlik Ozellikleri. Gazi Universitesi Gazi Egitim Fakultesi Dergisi, 22(1).

Sprecher, S., \& Fehr, B. (2005). Compassionate love for close others and humanity. Journal of Social and Personal Relationships, 22(5), 629-651. https://doi.org/10.1177/0265407505056439

Tatum, K. J. (2012).Adherence to Gender Roles as a Predictor of Compassion and Self-Compassion in Women and Men. Baylor University, Doctoral dissertation. 2012.

\section{Copyrights}

Copyright for this article is retained by the author(s), with first publication rights granted to the journal.

This is an open-access article distributed under the terms and conditions of the Creative Commons Attribution license which permits unrestricted use, distribution, and reproduction in any medium, provided the original work is properly cited. 